\title{
Adiponectin inhibits insulin-like growth factor-1-induced cell migration by the suppression of extracellular signal-regulated kinase $1 / 2$ activation, but not Akt in vascular smooth muscle cells
}

\author{
Yuki Motobayashi ${ }^{1,4}$, Yuki Izawa-Ishizawa ${ }^{1,4}$, Keisuke Ishizawa ${ }^{1}$, Sakiko Orino ${ }^{1}$, Kunihisa Yamaguchi $^{1}$, \\ Kazuyoshi Kawazoe $^{2}$, Shuichi Hamano ${ }^{1}$, Koichiro Tsuchiya ${ }^{3}$, Shuhei Tomita ${ }^{1}$ and Toshiaki Tamaki ${ }^{1}$
}

Adiponectin, an adipocyte-derived hormone, has been proposed to show antiatherogenic properties through the inhibitory effects against various growth factors. Insulin-like growth factor-1 (IGF-1) is one of the potent mitogens, which has been considered to play important roles in both atherogenesis and plaque stabilization in accordance to the phase of atherosclerosis. The aim of this study is to elucidate the adiponectin effects on IGF-1-induced cell migration and its intracellular signaling pathways in vascular smooth muscle cells (VSMCs). In this study, we assessed cell migration and several kinase activities in cultured rat aortic smooth muscle cells (RASMCs). Adiponectin pretreatment suppressed IGF-1-induced cell migration and extracellular signal-regulated kinase (ERK)1/2 activation, which is one of the major mediators for IGF-1-induced cell migration. In RASMCs, adiponectin and 5-aminoimidazole-4-carboxamide riboside (AICAR), a 5'-AMP-activated protein kinase (AMPK) activator, stimulated AMPK activation. AMPK activation by AICAR inhibited IGF-1-induced ERK1/2 activation and cell migration in RASMCs. On the other hand, phosphorylation of Akt and Bad, proapoptotic molecules of the Bcl-2 family, which were increased by IGF-1 stimulation, was not diminished by the pretreatment with adiponectin. It was shown that adiponectin inhibited IGF-1induced VSMC migration through suppression of ERK1/2 activation, which might be implicated in AMPK activation.

Furthermore, adiponectin selectively inhibited ERK1/2 pathway, not Akt-Bad pathway, stimulated by IGF-1. From these findings, it was implied that adiponectin suppressed IGF-1-induced VSMC migration and its signaling selectivity.

Hypertension Research (2009) 32, 188-193; doi:10.1038/hr.2008.19; published online 30 January 2009

Keywords: adiponectin; insulin-like growth factor-1; extracellular signal-regulated kinase 1/2; cell migration; vascular smooth muscle cell

\section{INTRODUCTION}

Adiponectin is a novel adipocyte-derived hormone, which has been proposed to play an important role in the regulation of energy homeostasis and insulin sensitivity. ${ }^{1}$ Adiponectin forms homomultimers from trimers and hexamers to high-molecular-weight (HMW) multimers. ${ }^{2}$ It has been reported that adiponectin, especially of HMW, forms show properties against cardiovascular diseases in several epidemiological studies. A Japanese case-control study showed that patients with hypoadiponectinemia showed increased risk of coronary artery diseases and multiple metabolic risk factors. ${ }^{3}$ In addition, a prospective study confirmed that high-serum adiponectin concentrations are associated with reduced risk of acute myocardial infarction in men. ${ }^{4}$ As the primary cause of many fatal cardiovascular diseases is believed to be atherosclerosis, it is important to clarify the antiathero- genic properties of adiponectin. The adiponectin effects against atherosclerosis are in fact suggested by in vivo studies using adiponectin-deficient mice. ${ }^{5,6}$ It has been reported that adiponectin knockout mice showed severe neointimal thickening and increased proliferation of vascular smooth muscle cells (VSMCs) in response to mechanical vascular injury. ${ }^{5,6}$ In an in vitro study, adiponectin has been reported to suppress high-glucose-induced reactive oxygen species in vascular endothelial cells by the activation of $5^{\prime}$-AMPactivated protein kinase (AMPK), which is known as a major molecule stimulated by adiponectin. ${ }^{7}$ Another study showed that adiponectin inhibited vascular endothelial growth factor-induced migration of human coronary artery endothelial cells through AMPK pathway. ${ }^{8}$ These studies have supported the antiatherogenic properties of adiponectin.

${ }^{1}$ Department of Pharmacology, The Institute of Health Bioscience, The University of Tokushima Graduate School, Tokushima, Japan; ${ }^{2}$ Department of Pharmacy, Tokushima University Hospital, Tokushima, Japan and ${ }^{3}$ Department of Medical Pharmacology, The Institute of Health Bioscience, The University of Tokushima Graduate School, Tokushima, Japan Correspondence: Dr K Ishizawa, Department of Pharmacology, The Institute of Health Bioscience, The University of Tokushima Graduate School, 3-18-15, Kuramoto, Tokushima 770-8503, Japan.

${ }^{4}$ These authors contributed equally to this work.

E-mail: ikeisuke@basic.med.tokushima-u.ac.jp

Received 7 May 2008; revised 27 October 2008; accepted 29 November 2008; published online 30 January 2009 
In the early phase of atherogenesis, VSMC migration is considered to play a crucial role. VSMC migration is induced by various inflammatory cytokines and chemokines. Insulin-like growth factor1 (IGF-1) is known as a potent mitogen to cause VSMC migration and proliferation. ${ }^{9}$ Several reports have indicated that IGF-1-induced VSMC migration is associated with the pathogenesis of atherosclerosis. It was shown that serum IGF-1 level was higher in the hypertensive patients with carotid plaque than in the hypertensive patients without plaque or normotensive controls. ${ }^{10}$ Overexpression of dominantnegative IGF-1 receptor in rat carotid arteries inhibited neointimal formation after balloon angioplasty through suppression of VSMC migration and proliferation. ${ }^{11}$ These reports revealed that IGF-1 promoted atherogenesis while causing VSMC migration. To regulate or control IGF-1-induced VSMC migration seems to be effective for preventing progression of atherosclerosis. Therefore, there are many reports on intracellular signaling pathways related to IGF-1-induced cell migration, such as protein kinase C, Nox4 and Rac1. ${ }^{9,12-14}$ It is reported that IGF-1-induced cell migration required extracellular signal-regulated kinase (ERK)1/2 activation and p38 mitogen-activated protein (MAP) kinase as one of the major mediators. ${ }^{9,15}$ Depletion of ERK1/2 activation using antisense oligonucleotide inhibited IGF-1-induced VSMC migration and proliferation. ${ }^{9}$ It suggested that downregulation of ERK1/2 was effective for control of VSMC migration. Meanwhile, IGF-1 receptor activation inhibited oxidized low-density lipoprotein-induced apoptosis through the phosphatidylinositol 3-kinase (PI3K)/Akt signaling pathway in VSMCs. ${ }^{16}$ It was also reported that IGF-1 phosphorylated Bad, a proapoptotic molecule of the Bcl-2 family, through the activation of PI3K/Akt pathway. ${ }^{17}$ Thus, IGF-1 is considered to cause several cell functions in VSMCs.

Adiponectin has been reported to inhibit platelet-derived growth factor (PDGF)- or heparin-binding epidermal growth factor-like growth factor (HB-EGF)-induced VSMC migration. ${ }^{18}$ In this study, it was suggested that adiponectin partially inhibit the postreceptor ERK1/2-mediated signaling pathway of these growth factors. ${ }^{18}$ However, it has not been elucidated yet whether adiponectin attenuates IGF-1-induced VSMC migration, or affects its intracellular signaling pathways. In this study, we investigated the effects of adiponectin on IGF-1-induced cell migration and intracellular signaling pathway in cultured rat aortic smooth muscle cells (RASMCs).

\section{METHODS}

\section{Cells and materials}

RASMCs were isolated from male Sprague-Dawley rats weighing 200-250 g and maintained in $10 \%$ fetal bovine serum and Dulbecco's modified Eagle's medium (DMEM) as described previously. ${ }^{19}$ Cells were seeded $\left(1-2 \times 10^{4}\right.$ cells/ $\mathrm{cm}^{2}$ ) and grown to subconfluence in $60-\mathrm{mm}$ culture dishes (IWAKI, Chiba, Japan) in DMEM-10\% FBS. For experiments, cells from passages 3 to 8 were used after $24-48 \mathrm{~h}$ of serum depletion. Human recombinant IGF-1 was purchased from Sigma (St Louis, MO, USA). Murine full-length adiponectin, a recombinant protein, was purchased from Biovendor Laboratory Medicine Inc. (Modrice, Czech Republic). Phospho-ERK1/2 antibody $\left(\mathrm{Thr}^{202} / \mathrm{Tyr}^{204}\right.$ ), phospho-p38 MAP kinase antibody $\left(\mathrm{Thr}^{180} / \mathrm{Tyr}^{182}\right)$, phospho-Akt antibody $\left(\mathrm{Ser}^{473}\right)$, phospho-Bad antibody $\left(\mathrm{Ser}^{136}\right)$, phospho-AMPK $\alpha\left(\mathrm{Thr}^{172}\right)$ antibody, Akt antibody and AMPK $\alpha$ antibody were purchased from Cell Signaling Technology Inc. (Beverly, MA, USA). ERK1/2 antibody and was purchased from Santa Cruz Biotechnology Inc. (Santa Cruz, CA, USA). Bad antibody was purchased from BD Biosciences (San Jose, CA, USA). AMPK activator, 5aminoimidazole-4-carboxamide riboside (AICAR), was purchased from Calbiochem (San Diego, CA, USA). MEK1/2 inhibitor, PD98059, was from Wako Pure Chemical Industries Ltd (Osaka, Japan). All other chemicals were of reagent grade and obtained from commercial sources, and were used without further purification.

\section{Cell migration}

To assess cell migration, a modified Boyden chamber assay was performed by minor modification to the method described previously. ${ }^{19}$ The assay was performed using Transwell chambers (6.5 mm, model 3422; Costar, Cambridge, MA, USA) with an $8-\mu \mathrm{m}$ pore polycarbonate membrane. The underside of the polycarbonate membrane was coated with $5 \mu \mathrm{g} \mathrm{ml}^{-1}$ collagen I rat tail (3.78 mg ml ${ }^{-1}$, model 35-4236; Collaborative Biochemical Products, Bedford, MA, USA) overnight at $4{ }^{\circ} \mathrm{C}$. Later, the lower chamber was blocked with DMEM $/ 0.1 \%$ bovine serum albumin for $30 \mathrm{~min}$ at room temperature. Growtharrested cells were harvested, washed and suspended in serum-free DMEM. Cells were added to the upper chamber of the Transwell at $5 \times 10^{5}$ cells in $100 \mu \mathrm{l} /$ well. A total of $600 \mu \mathrm{l}$ of serum-free DMEM was added to the lower chamber and then pretreated with or without adiponectin, PD98059, SB203580 or AICAR in the lower chamber for $30 \mathrm{~min}$ at $37^{\circ} \mathrm{C}$ followed by treatment with or without IGF-1 in the lower chamber, and cells were allowed to migrate at $37^{\circ} \mathrm{C}$. After $6 \mathrm{~h}$ of incubation, the nonmigratory cells were removed from the upper surface of the membrane by scraping off with cotton swabs. Membrane was fixed with methanol, stained with Diff-Quik solution (Baxter, McGaw Park, IL, USA) and allowed to air-dry at room temperature. Later, the membrane was excised from the plastic supports with a sharp scalpel and mounted on a glass slide using Permount (Sigma Chemical, St Louis, MO, USA). Migrated cells were counted at $\times 400$ magnification in 10 microscope fields per filter.

\section{Preparation of cell lysate for immunoblotting and western blot analysis}

Quiescent cells were treated with or without IGF-1, adiponectin, PD98059 and AICAR at indicated times and concentrations. Later, incubation media were discarded, and the cells were lysed with cell lysis buffer $\left(20 \mathrm{mmoll}^{-1}\right.$ Tris- $\mathrm{HCl}, \mathrm{pH}$ 7.4, $150 \mathrm{mmoll}^{-1} \mathrm{NaCl}, 1 \mathrm{mmoll}^{-1}$ EDTA, $1 \mathrm{mmoll}^{-1}$ EGTA (ethylene glycol bis( $\beta$-aminoethylether)- $N, N, N^{\prime}, N^{\prime}$,-tetraacetic acid), $1 \%$ Triton X-100, $2.5 \mathrm{mmoll}^{-1}$ sodium pyrophosphate, $1 \mathrm{mmoll}^{-1} \beta$-glycerophosphate, $1 \mathrm{mmoll}^{-1}$ sodium orthovanadate, $1 \mu \mathrm{g} \mathrm{ml}^{-1}$ leupeptin and $1 \mathrm{mmoll}^{-1}$ phenylmethylsulfonyl fluoride). After freeze-thawing, lysed cells were transferred to microcentrifuge tubes, sonicated (Handy Sonic UR-20 P; Tomy Seiko Co., Ltd, Tokyo, Japan) on ice and centrifuged at $20000 \mathrm{~g}$ for $20 \mathrm{~min}$ at $4{ }^{\circ} \mathrm{C}$. The protein concentrations of the supernatants were measured with a protein assay kit (Bio-Rad, Hercules, CA, USA) and stored at $-80^{\circ} \mathrm{C}$ until performing immunoblotting.

For western blot analysis, cell lysates were subjected to sodium dodecyl sulfate-polyacrylamide gel electrophoresis, and proteins were transferred to nitrocellulose membranes (Hybond-ECL; Amersham Pharmacia Biotech, Buckinghamshire, England, UK), as described previously. The membranes were blocked for $1 \mathrm{~h}$ at room temperature with $5 \%$ bovine serum albumin. The blots were then incubated for $12 \mathrm{~h}$ with anti-phospho-specific ERK1/2, anti-phospho-specific AMPK, anti-phospho-specific Akt $\left(\mathrm{Ser}^{473}\right)$ and anti-phosphospecific Bad antibody, followed by incubation for $1 \mathrm{~h}$ with a secondary antibody (horseradish peroxidase conjugated). Immunoreactive bands were visualized using enhanced chemiluminescence (Amersham Pharmacia Biotech) and were quantified by densitometry in the linear range of film exposure using a UMAX Astra 2200 scanner (UMAX Technologies, Fremont, CA, USA) and ImageJ $1.31 \mathrm{v}$ software.

\section{Statistical analysis}

Values are reported as the means \pm s.d. from experiments performed in five different occasions. Two-way analysis of variance was used to determine the significance among groups, after which the modified $t$-test with the Bonferroni's post hoc test was used for comparison between individual groups. A value of $P<0.05$ was considered to be statistically significant.

\section{RESULTS}

Adiponectin inhibits IGF-1-induced RASMC migration

We confirmed that IGF-1 increased RASMC migration in concentration-dependent manner (1, 10 and $100 \mathrm{ng} \mathrm{ml}^{-1}$ ) (Figure 1a) by a modified Boyden chamber assay as described in the Methods section. Pretreatment with PD98059 $\left(10 \mu \mathrm{moll}^{-1}, 30 \mathrm{~min}\right)$, an MEK1/2 inhibitor, or SB203580 $\left(10 \mu \mathrm{moll}^{-1}, 30 \mathrm{~min}\right)$, a p38 MAP kinase inhibitor, 
a
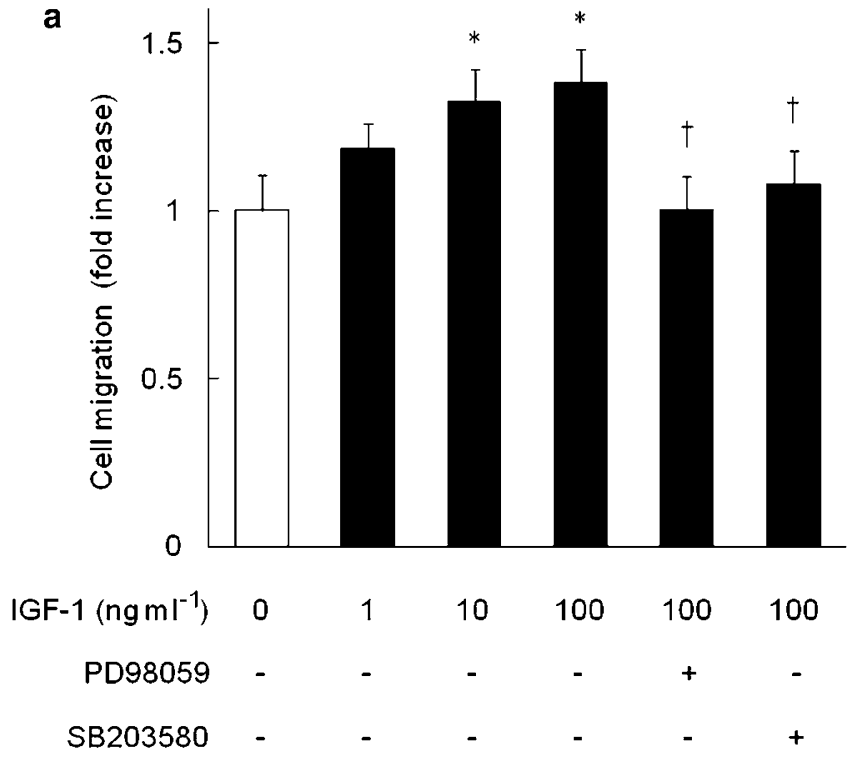

b

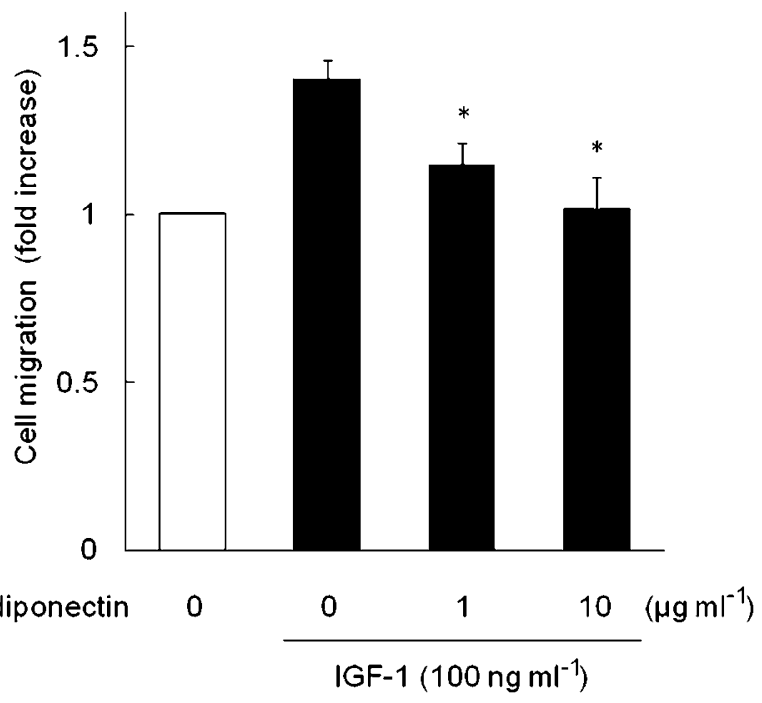

Figure 1 IGF-1-induced RASMC migration. (a) Concentration-dependent increase in IGF-1-induced RASMC migration and the effects of PD98059, a MEK1/2 inhibitor, or SB203580, a p38 MAP kinase inhibitor. Cells were treated with indicated concentration of PDGF for $6 \mathrm{~h}$ with or without the pretreatment of PD98059 $\left(10 \mu \mathrm{moll}^{-1}, 30 \mathrm{~min}\right)$, or SB203580 $\left(10 \mu \mathrm{mol} \mathrm{I}^{-1}, 30 \mathrm{~min}\right)$. And later, a modified Boyden chamber assay was performed as described in the Methods section. Values were normalized by arbitrarily setting the fold increases in the migration of control cells (without IGF-1 treatment) to 1.0 (values are the means \pm s.d., $n=5,{ }^{*} P<0.05$ vs. control cells, ${ }^{\dagger} P<0.05$ vs. IGF-1 $100 \mathrm{ng} \mathrm{m}^{-1}$ without adiponectin). (b) Adiponectin concentration-dependent suppression of IGF-1-induced RASMC migration. Cells were treated with indicated concentration of adiponectin $30 \mathrm{~min}$ before treatment with IGF-1 $\left(100 \mathrm{ng} \mathrm{ml}^{-1}\right)$ for $6 \mathrm{~h}$. Values were normalized by arbitrarily setting the fold increases in the migration of control cells (without IGF-1 treatment) to 1.0 (values are the means \pm s.d., $n=5,{ }^{*} P<0.05$ vs. IGF-1 $100 \mathrm{ng} \mathrm{ml}^{-1}$ without adiponectin).

suppressed IGF-1-induced RASMC migration to the control level (Figure 1a). To examine whether adiponectin affect on IGF-1-induced VSMC migration, growth-arrested RASMCs were treated with or without adiponectin $\left(1\right.$ and $\left.10 \mu \mathrm{g} \mathrm{ml}^{-1}\right)$ for $30 \mathrm{~min}$ before stimulation with IGF-1 $\left(100 \mathrm{ng} \mathrm{ml}^{-1}, 6 \mathrm{~h}\right)$. In this study, we used adiponectin recombinant of full-length form, which exists mainly as in plasma. ${ }^{20}$

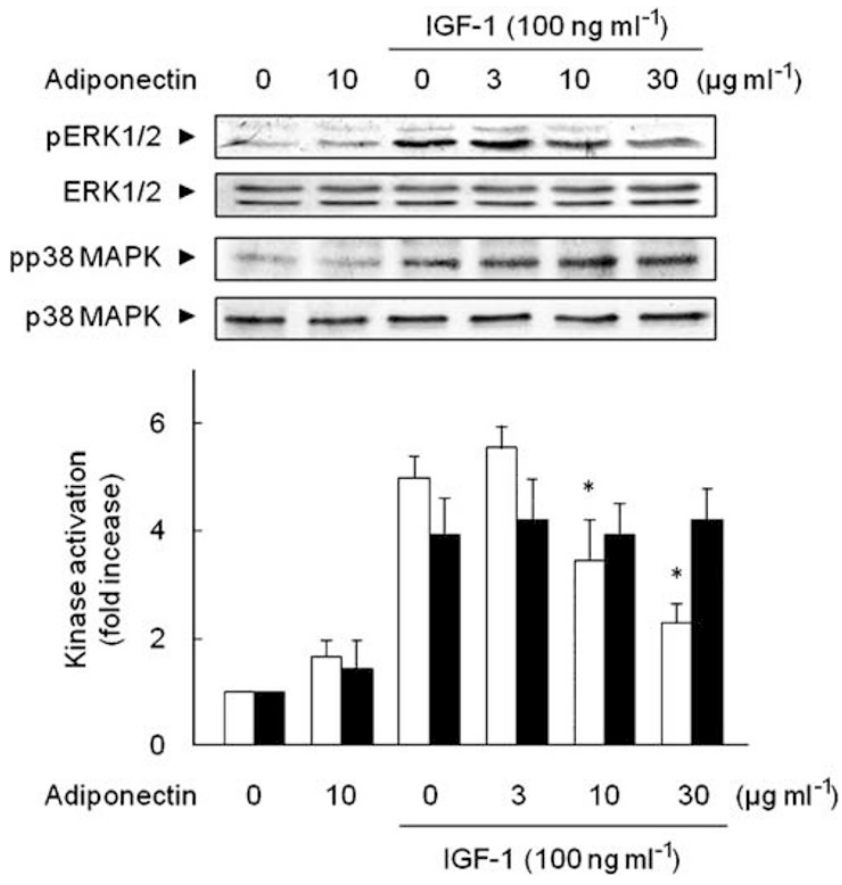

Figure 2 Effect of adiponectin on IGF-1-induced ERK1/2 and p38 MAP kinase activation in RASMCs. Cells were treated with indicated concentration of adiponectin $30 \mathrm{~min}$ before treatment with IGF-1 (100 ng ml-1) for $10 \mathrm{~min}$. No significant differences in the amounts of total ERK $1 / 2$ and p38 MAP kinase were observed on western blot analysis with anti-ERK1/2 antibody or anti-p38 MAP kinase antibody. Upper panel shows the representative blot. Lower graph shows the result of densitometric analysis. Open columns indicate ERK1/2 activation and closed columns indicate p38 MAP kinase activation. Values were normalized by arbitrarily setting the densitometry of control cells (time $=0$, without IGF-1) to 1.0 (values are the means \pm s.d., $n=5,{ }^{*} P<0.05$ vs. IGF- $1100 \mathrm{ng} \mathrm{ml}^{-1}$ without adiponectin).

As shown in Figure 1b, IGF-1 $\left(100 \mathrm{ng} \mathrm{m}^{-1}\right)$ increased RASMC migration (1.4-fold increase compared with the untreated control cells), and adiponectin pretreatment suppressed IGF-1-induced RASMC migration in concentration-dependent manner ( 1 and $\left.10 \mu \mathrm{g} \mathrm{ml}^{-1}\right)$. As it was confirmed that IGF-1-induced cell migration, at least in part, is mediated by ERK1/2 and p38 MAP kinase activation as shown in Figure 1a, we focused on the effect of adiponectin on IGF-1-induced ERK1/2 and p38 MAP kinase activation in RASMCs. As shown in Figure 2, ERK1/2 activation stimulated by IGF-1 $\left(100 \mathrm{ng} \mathrm{ml}^{-1}, 10 \mathrm{~min}\right)$ was significantly suppressed by adiponectin (10 and $30 \mu \mathrm{g} \mathrm{ml}^{-1}$ ) pretreatment. However, IGF-1-induced p38 MAP kinase activation was not suppressed by adiponectin pretreatment. From these results it was suggested that the inhibitory effect of adiponectin on IGF-1-induced RASMC migration was mediated by the suppression of ERK1/2 activation.

\section{AMPK activation inhibits IGF-1-induced ERK1/2 activation and cell migration in RASMCs}

Adiponectin has been reported to activate AMPK by adiponectin receptor activation in several cells. ${ }^{21}$ Therefore, we hypothesized that AMPK is a key molecule for the crosstalk between adiponectin- and IGF-1-induced intracellular signaling pathways. In RASMCs, adiponectin $\left(10 \mu \mathrm{g} \mathrm{ml}^{-1}\right)$ and AICAR $\left(1 \mathrm{mmoll}^{-1}\right)$, an AMPK activator, activated AMPK rapidly 2.3- and 2.5-fold increase, respectively, compared with untreated control cells. Compound C $\left(20 \mu \mathrm{moll}^{-1}\right)$ 


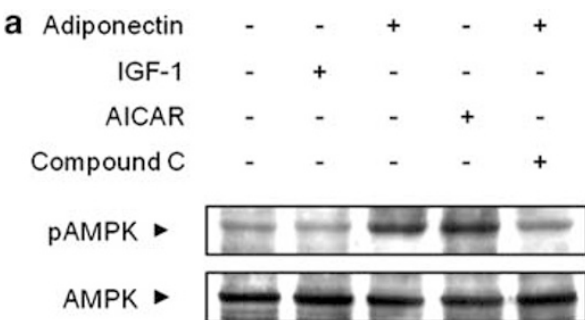

$\begin{array}{rrrrr}\text { b Adiponectin } & - & - & - & + \\ \text { IGF-1 } & - & + & + & + \\ \text { AICAR } & - & - & + & - \\ \text { Compound C } & - & - & - & +\end{array}$
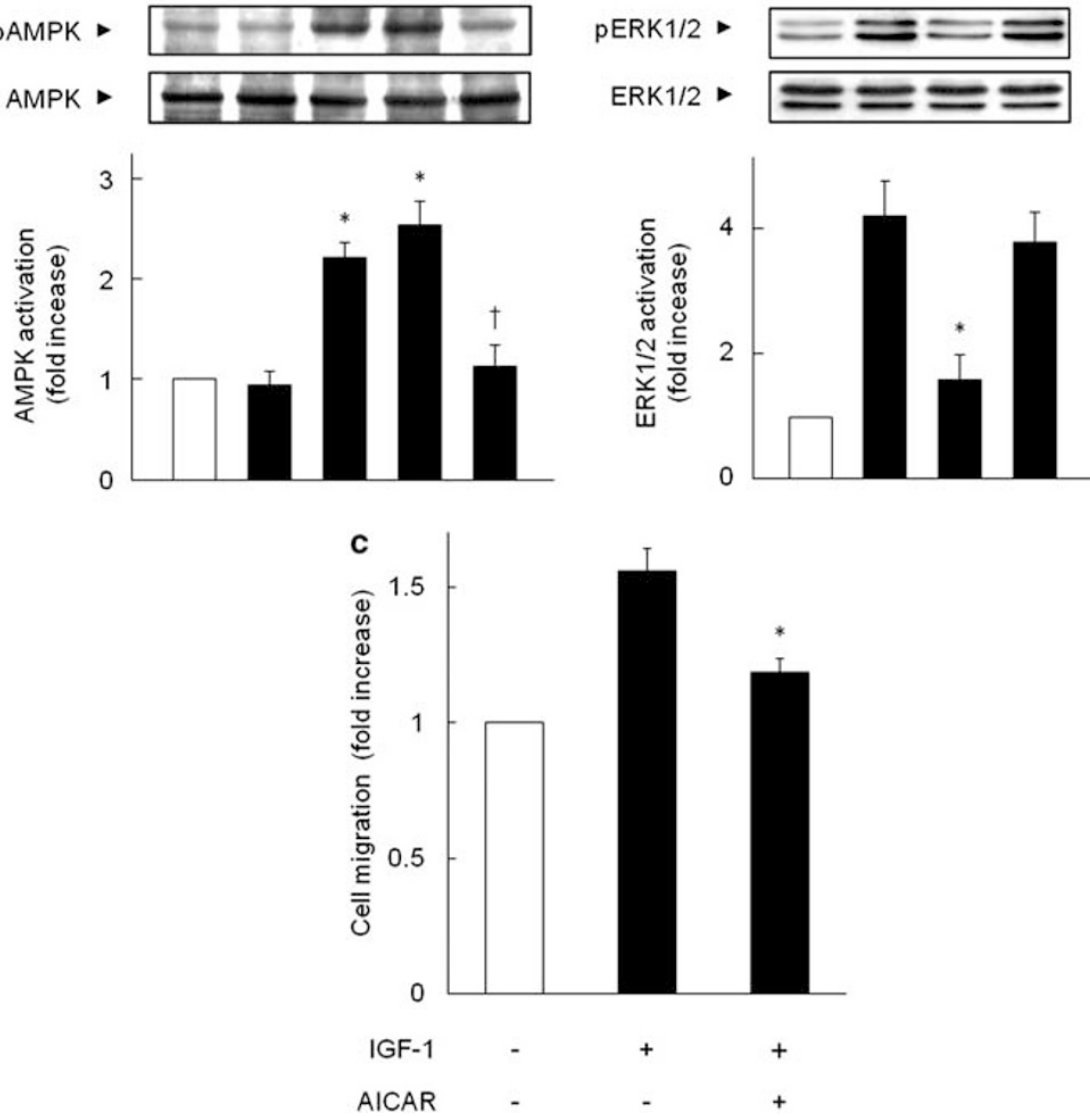

Figure 3 Effects of AICAR, an activator of AMPK. (a) The results of AMPK activities induced by IGF-1 (100 ng ml ${ }^{-1}, 10 \mathrm{~min}^{2}$, adiponectin (10 $\mu \mathrm{gml} \mathrm{I}^{-1}$, $30 \mathrm{~min})$ or AICAR $\left(1 \mathrm{mmolI}^{-1}, 30 \mathrm{~min}\right)$, and the effect of compound $\mathrm{C}\left(20 \mu \mathrm{moll}^{-1}, 30 \mathrm{~min}\right)$ were shown. No significant differences in the amounts of total AMPK were observed on western blot analysis with anti-AMPK antibody. Upper panel shows the representative blot. Lower graph shows the result of densitometric analysis. Values were normalized by arbitrarily setting the fold increases in the absorbance of control cells to 1.0 (values are the means \pm s.d., $n=5$, ${ }^{*} P<0.05$ vs. control, ${ }^{\dagger} P<0.05$ vs. adiponectin alone). (b) The results of the effects of AICAR or compound C on IGF-1-induced ERK1/2 activation were shown. Cells were pretreated with or without AICAR $\left(1 \mathrm{mmoll}{ }^{-1}, 30 \mathrm{~min}\right)$ or compound $\mathrm{C}\left(20 \mu \mathrm{moll} \mathrm{I}^{-1}, 30 \mathrm{~min}\right)$ after treatment with or without adiponectin $\left(10 \mu \mathrm{gl}^{-1}, 30 \mathrm{~min}\right)$ and/or IGF-1 $\left(100 \mathrm{ng} \mathrm{ml}^{-1}, 10 \mathrm{~min}\right)$. No significant differences in the amounts of total ERK1/2 were observed on western blot analysis with anti-ERK1/2 antibody. Upper panel shows the representative blot. Lower graph shows the result of densitometric analysis. Values were normalized by arbitrarily setting the densitometry of control cells to 1.0 (values are the means \pm s.d., $n=5,{ }^{*} P<0.05 \mathrm{vs}$. IGF-1 $100 \mathrm{ng} \mathrm{ml}{ }^{-1}$ alone). (c) The results of the effect of AICAR on IGF-1-induced RASMC migration are shown. Cells were pretreated with or without AICAR $\left(1 \mathrm{mmol} \mathrm{I}^{-1}\right)$ for $30 \mathrm{~min}$ after incubation with IGF-1 for $6 \mathrm{~h}$. Values were normalized by arbitrarily setting the densitometry of control cells to 1.0 (values are the means \pm s.d., $n=5$, ${ }^{*} P<0.05$ vs. IGF-1 $100 \mathrm{ng} \mathrm{ml}^{-1}$ without AICAR).

significantly suppressed adiponectin-induced AMPK activation. However, IGF-1 had no effect on AMPK activation in RASMCs (Figure 3a). As shown in Figure 3b, IGF-1-induced ERK1/2 activation was inhibited by AICAR pretreatment. It was showed that AMPK activation attenuated IGF-1-induced ERK1/2 activation in RASMCs. Moreover, treatment with compound $\mathrm{C}$ restored adiponectinimpaired ERK1/2 activation by IGF-1. It was suggested that the inhibitory effect of adiponectin on IGF-1-induced ERK1/2 activation was mediated by AMPK activation. As shown in Figure $3 c$, it was confirmed that IGF-1-induced RASMC migration was inhibited by AICAR. These results suggested that the inhibitory effect of adiponectin on IGF-1-induced ERK1/2 activation was mediated by AMPK activation by adiponectin, leading to the suppression of RASMC migration.

\section{Adiponectin had no effect on IGF-1-induced Akt and Bad} phosphorylation in RASMCs

IGF-1 has been also reported to activate the Akt-Bad pathway, and to have anti-apoptotic effect. ${ }^{17}$ To confirm the adiponectin effects on this pathway in RASMCs, phosphorylation of Akt and Bad induced by IGF-1 was examined. Phosphorylation of Akt and Bad increased by IGF-1 stimulation was not diminished by the pretreatment with adiponectin $\left(3,10\right.$ and $30 \mu \mathrm{g} \mathrm{ml}^{-1}$ ) (Figure 4). From these results, it was implied that IGF-1-stimulated ERK1/2 pathway was suppressed selectively, not the Akt-Bad pathway, by adiponectin.

\section{DISCUSSION}

In this study, we showed that adiponectin inhibited IGF-1-induced RASMC migration through suppression of ERK1/2 activation. 


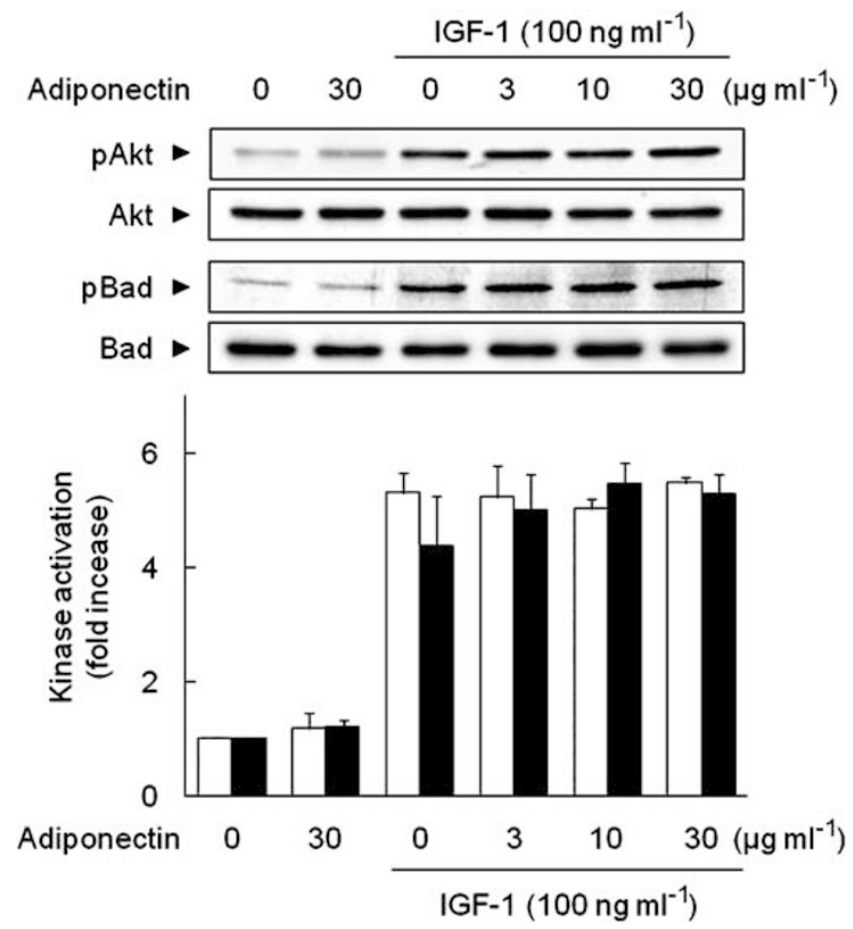

Figure 4 Effects of adiponectin on IGF-1-induced phosphorylation of Akt and Bad. Cells were treated with indicated concentration of adiponectin $30 \mathrm{~min}$ before treatment with IGF-1 $\left(100 \mathrm{ng} \mathrm{ml}^{-1}\right)$ for $10 \mathrm{~min}$. No significant differences in the amounts of total Akt and Bad were observed on western blot analysis with anti-Akt or anti-Bad antibody. Upper panel shows the representative blots. Lower graph shows the result of densitometric analysis (open column: phosphorylated Akt; closed column: phosphorylated Bad). Values were normalized by arbitrarily setting the densitometry of control cells to 1.0 (values are the means \pm s.d., $n=5$ ).

AICAR, an AMPK activator, also inhibited IGF-1-induced ERK1/2 activation and RASMC migration. Furthermore, adiponectin selectively inhibited ERK1/2 pathway, not the Akt-Bad pathway, stimulated by IGF-1 in RASMCs. From these results, it was suggested that adiponectin can attenuate the atherogenesis by suppression of IGF1 -induced VSMC migration through AMPK activation.

In many cases and in various types of cells, antiatherogenic properties of adiponectin are exerted by the inhibition of deleterious stimulation such as angiotensin II, tumor necrosis factor- $\alpha$ (TNF- $\alpha$ ), high glucose, several growth factors, etc. ${ }^{7,8,22}$ It was shown that adiponectin protected against angiotensin II- or TNF- $\alpha$-induced endothelial cell monolayer hyperpermeability. ${ }^{22}$ In other study, it was shown that adiponectin inhibited TNF- $\alpha$-induced VSMC calcification. ${ }^{23}$ Adding to these observations, we showed that adiponectin inhibited IGF-1-induced cell migration in RASMCs (Figure 1b). As it has already been reported that PDGF- or HB-EGF-induced VSMC migration is inhibited by adiponectin, ${ }^{18}$ it was proven that adiponectin was a potent inhibitor for VSMC migration in response to various growth factors. In some studies, it was reported that adiponectin's inhibitory effects were due to the binding to growth factors, and that adiponectin blocked the binding between growth factors and their receptors. ${ }^{18}$ However, as we have shown in this study, adiponectin inhibited ERK1/2 pathway and did not affect the alternative pathways, p38 MAP kinase activation or Akt-Bad phosphorylation. These results indicated that there is some crosstalk between adiponectin- and IGF1-stimulated intracellular signaling pathways. Recently, adiponectinstimulated signaling pathways have become apparent gradually. It has been reported that adiponectin transmits signaling by binding to adiponectin receptor 1 or 2, which leads to activation of AMPK and cAMP-protein kinase A signaling. ${ }^{1}$ The role of AMPK in adiponectin (that of exerting its salutary effects on cardiovascular function) has been strongly implicated in recent studies. ${ }^{21}$ Adiponectin-induced phosphorylation of endothelial nitric oxide synthase (eNOS) required AMPK activation in endothelial cells. ${ }^{24}$ Adiponectin inhibits angiotensin II, $\alpha$-adrenergic receptor stimulation or pressure overloadinduced hypertrophic signaling in the myocardium through AMPK activation. $^{21}$

Indeed, we showed that AMPK activation by AICAR inhibited IGF1-induced ERK1/2 activation and VSMC migration (Figure 3). Consistent with our results, the inhibitory crosstalk between ERK1/2 and AMPK has been published recently. ${ }^{25,26}$ AMPK activation by adiponectin suppressed angiotensin II-induced cardiac fibrosis through inhibition of ERK1/2 and activation of peroxisome proliferatoractivated receptor- $\alpha$ (PPAR- $\alpha) .{ }^{25}$ In NIH-3T3 cells, AICAR-stimulated AMPK activation downregulated IGF-1- or epidermal growth factordependent ERK1/2 pathway and cell proliferation. ${ }^{26}$ As shown in Figure 3a, we confirmed that adiponectin activated AMPK in RASMCs. It was supposed that the inhibitory effect of adiponectin on VSMC migration was also because of AMPK activation.

On the other hand, the role of IGF-1 on the pathogenesis of atherosclerosis has been still controversial. As shown in Figure 4, we confirmed that IGF-1 stimulated the Akt-Bad pathway. It is considered that IGF-1-stimulated Bad phosphorylation mediates anti-apoptotic signaling. ${ }^{17}$ Suppression of VSMC apoptosis by IGF-1 serves to protect against plaque instability and rupture, especially in the late phase of atherosclerosis. ${ }^{27,28}$ According to the study using carotid artery specimens from patients with atherosclerosis, expressions of IGF-1 and IGF-1 receptor in plaque VSMCs were significantly greater in asymptomatic subjects compared with symptomatic subjects. ${ }^{27}$ Moreover, it was reported that low-serum IGF-1 level was associated with increased risk of ischemic heart disease. ${ }^{28}$ Gathering these evidences, it is suggested that IGF-1 has dual effects, for and against atherosclerosis. Therefore, it is desirable to downregulate the IGF-1induced mitogenic effects in the early phase of atherosclerosis, and also to sustain IGF-1-induced anti-apoptotic signaling in the late phase of the plaque formation. However, there has been no study, either experimental or clinical, reporting success in regulating IGF-1 action on vasculatures. Unveiling the precise mechanisms of adiponectin's effects on IGF-1 signaling could serve as a new strategy for overcoming cardiovascular diseases.

1 Kadowaki T, Yamauchi T, Kubota N, Hara K, Ueki K, Tobe K. Adiponectin and adiponectin receptors in insulin resistance, diabetes, and the metabolic syndrome. J Clin Invest 2006; 116: 1784-1792.

2 Waki H, Yamauchi T, Kamon J, Ito Y, Uchida S, Kita S, Hara K, Hada Y, Vasseur F, Froguel P, Kimura S, Nagai R, Kadowaki T. Impaired multimerization of human adiponectin mutants associated with diabetes. Molecular structure and multimer formation of adiponectin. J Biol Chem 2003; 278: 40352-40363.

3 Kumada M, Kihara S, Sumitsuji S, Kawamoto T, Matsumoto S, Ouchi N, Arita Y, Okamoto Y, Shimomura I, Hiraoka H, Nakamura T, Funahashi T, Matsuzawa Y. Association of hypoadiponectinemia with coronary artery disease in men. Arterioscler Thromb Vasc Biol 2003; 23: 85-89.

4 Pischon T, Girman CJ, Hotamisligil GS, Rifai N, Hu FB, Rimm EB. Plasma adiponectin levels and risk of myocardial infarction in men. JAMA 2004; 291: 1730-1737.

5 Kubota N, Terauchi Y, Yamauchi T, Kubota T, Moroi M, Matsui J, Eto K, Yamashita T, Kamon J, Satoh H, Yano W, Froguel P, Nagai R, Kimura S, Kadowaki T, Noda T. Disruption of adiponectin causes insulin resistance and neointimal formation. J Biol Chem 2002; 277: 25863-25866.

6 Matsuda M, Shimomura I, Sata M, Arita Y, Nishida M, Maeda N, Kumada M, Okamoto Y, Nagaretani H, Nishizawa H, Kishida K, Komuro R, Ouchi N, Kihara S, Nagai R, 
Funahashi T, Matsuzawa Y. Role of adiponectin in preventing vascular stenosis. The missing link of adipo-vascular axis. J Biol Chem 2002; 277: 37487-37491.

7 Ouedraogo R, Wu X, Xu SQ, Fuchsel L, Motoshima H, Mahadev K, Hough K, Scalia R, Goldstein BJ. Adiponectin suppression of high-glucose-induced reactive oxygen species in vascular endothelial cells: evidence for involvement of a cAMP signaling pathway. Diabetes 2006; 55: 1840-1846.

8 Mahadev K, Wu X, Donnelly S, Ouedraogo R, Eckhart A, Goldstein B. Adiponectin inhibits vascular endothelial growth factor-induced migration of human coronary artery endothelial cells. Cardiovasc Res 2008; 78: 376-384.

9 Duan $\mathrm{C}$. The chemotactic and mitogenic responses of vascular smooth muscle cells to insulin-like growth factor-I require the activation of ERK1/2. Mol Cell Endocrinol 2003; 206: 75-83.

10 Watanabe T, Itokawa M, Nakagawa Y, Iguchi T, Katagiri T. Increased levels of insulinlike growth factor binding protein-3 in hypertensive patients with carotid atherosclerosis. Am J Hypertens 2003; 16: 754-760.

11 Lim HJ, Park HY, Ko YG, Lee SH, Cho SY, Lee EJ, Jameson JL, Jang Y. Dominant negative insulin-like growth factor-1 receptor inhibits neointimal formation through suppression of vascular smooth muscle cell migration and proliferation, and induction of apoptosis. Biochem Biophys Res Commun 2004; 325: 1106-1114.

12 Yano K, Bauchat JR, Liimatta MB, Clemmons DR, Duan C. Down-regulation of protein kinase $C$ inhibits insulin-like growth factor I-induced vascular smooth muscle cell proliferation, migration, and gene expression. Endocrinology 1999; 140: 4622-4632.

13 Pukac L, Huangpu J, Karnovsky MJ. Platelet-derived growth factor-BB, insulin-like growth factor-I, and phorbol ester activate different signaling pathways for stimulation of vascular smooth muscle cell migration. Exp Cell Res 1998; 242: 548-560.

14 Meng D, Lv DD, Fang J. Insulin-like growth factor-I induces reactive oxygen species production and cell migration through Nox4 and Rac1 in vascular smooth muscle cells. Cardiovasc Res 2008; 80: 299-308.

15 Zhang X, Lin M, van Golen KL, Yoshioka K, Itoh K, Yee D. Multiple signaling pathways are activated during insulin-like growth factor-I (IGF-I) stimulated breast cancer cell migration. Breast Cancer Res Treat 2005; 93: 159-168.

16 Li Y, Higashi Y, Itabe H, Song YH, Du J, Delafontaine P. Insulin-like growth factor-1 receptor activation inhibits oxidized LDL-induced cytochrome $C$ release and apoptosis via the phosphatidylinositol 3 kinase/Akt signaling pathway. Arterioscler Thromb Vasc Biol 2003; 23: 2178-2184.

17 Bai H, Pollman MJ, Inishi Y, Gibbons GH. Regulation of vascular smooth muscle cell apoptosis. Modulation of Bad by a phosphatidylinositol 3-kinase-dependent pathway. Circ Res 1999; 85: 229-237.

18 Arita Y, Kihara S, Ouchi N, Maeda K, Kuriyama H, Okamoto Y, Kumada M, Hotta K, Nishida M, Takahashi M, Nakamura T, Shimomura I, Muraguchi M, Ohmoto Y, Funahashi T, Matsuzawa Y. Adipocyte-derived plasma protein adiponectin acts as a platelet-derived growth factor-BB-binding protein and regulates growth factor-induced common postreceptor signal in vascular smooth muscle cell. Circulation 2002; 105 : 2893-2898.

19 Izawa Y, Yoshizumi M, Ishizawa K, Fujita Y, Kondo S, Kagami S, Kawazoe K, Tsuchiya K, Tomita S, Tamaki T. Big mitogen-activated protein kinase 1 (BMK1)/extracellular signal regulated kinase 5 (ERK5) is involved in platelet-derived growth factor (PDGF)induced vascular smooth muscle cell migration. Hypertens Res 2007; 30: 1107-1117.

20 Fruebis J, Tsao TS, Javorschi S, Ebbets-Reed D, Erickson MR, Yen FT, Bihain BE, Lodish HF. Proteolytic cleavage product of $30-\mathrm{kDa}$ adipocyte complement-related protein increases fatty acid oxidation in muscle and causes weight loss in mice. Proc Natl Acad Sci USA 2001; 98: 2005-2010.

21 Shibata R, Ouchi N, Ito M, Kihara S, Shiojima I, Pimentel DR, Kumada M, Sato K, Schiekofer S, Ohashi K, Funahashi T, Colucci WS, Walsh K. Adiponectin-mediated modulation of hypertrophic signals in the heart. Nat Med 2004; 10: 1384-1389.

22 Xu SQ, Mahadev K, Wu X, Fuchsel L, Donnelly S, Scalia RG, Goldstein BJ. Adiponectin protects against angiotensin II or tumor necrosis factor alpha-induced endothelial cell monolayer hyperpermeability: role of cAMP/PKA signaling. Arterioscler Thromb Vasc Biol 2008; 28: 899-905.

23 Son B, Akishita M, lijima K, Kozaki K, Maemura K, Eto M, Ouchi Y. Adiponectin antagonizes stimulatory effect of tumor necrosis factor-alpha on vascular smooth muscle cell calcification: regulation of growth arrest-specific gene 6-mediated survival pathway by adenosine 5'-monophosphate-activated protein kinase. Endocrinology 2008; 149: 1646-1653.

24 Ouchi N, Kobayashi H, Kihara S, Kumada M, Sato K, Inoue T, Funahashi T, Walsh K. Adiponectin stimulates angiogenesis by promoting cross-talk between AMP-activated protein kinase and Akt signaling in endothelial cells. J Biol Chem 2004; 279: 1304-1309.

25 Fujita K, Maeda N, Sonoda M, Ohashi K, Hibuse T, Nishizawa H, Nishida M, Hiuge A, Kurata A, Kihara S, Shimomura I, Funahashi T. Adiponectin protects against angiotensin II-induced cardiac fibrosis through activation of PPAR-alpha. Arterioscler Thromb Vasc Biol 2008; 28: 863-870.

26 Kim J, Yoon MY, Choi SL, Kang I, Kim SS, Kim YS, Choi YK, Ha J. Effects of stimulation of AMP-activated protein kinase on insulin-like growth factor 1- and epidermal growth factor-dependent extracellular signal-regulated kinase pathway. J Biol Chem 2001; 276: 19102-19110.

27 Jia G, Cheng G, Soundararajan K, Agrawal DK. Insulin-like growth factor-I receptors in atherosclerotic plaques of symptomatic and asymptomatic patients with carotid stenosis: effect of IL-12 and IFN-gamma. Am J Physiol Heart Circ Physiol 2007; 292: $\mathrm{H} 1051-\mathrm{H} 1057$.

28 Juul A, Scheike T, Davidsen M, Gyllenborg J, J Jørgensen T. Low serum insulin-like growth factor I is associated with increased risk of ischemic heart disease: a populationbased case-control study. Circulation 2002; 106: 939-944. 